\title{
Pemanfaatan Budaya Posoropu dalam Perawatan Masa Nifas oleh Perempuan Buton Utara
}

\section{Utilization of Posoropu Tradition During the Postpartum Period in North Buton Regency}

\author{
Usman*, Sapril \\ Program Studi D-III Kebidanan Politeknik Baubau \\ (jovialusman@gmail.com)
}

\begin{abstract}
ABSTRAK
Masa nifas adalah masa setelah plasenta lahir dan berakhir ketika alat-alat kandungan kembali seperti keadaan sebelum hamil. Perempuan Buton memanfaatkan tradisi posoropu sebagai perawatan masa nifas yang dapat mempengaruhi status kesehatan. Penelitian bertujuan mengeksplorasi pemanfaatan tradisi posoropu saat masa nifas perempuan di Kecamatan Kulisusu, Kecamatan Bonegunu, dan Kecamatan Kulisusu Utara di Kabupaten Buton Utara. Sebuah studi kualitatif dengan pendekatan Etnografi, dilakukan dengan wawancara mendalam pada 14 informan yang didapatkan dengan purposive sampling. Dari hasil analisis tradisi posoropu saat masa nifas perempuan Buton, terdiri dari aspek sosial dan aspek budaya. Adapun aspek sosial, yaitu perempuan Buton memiliki self concept bahwa perawatan yang dilakukan oleh Bisa (dukun beranak) menimbulkan sentuhan magis, dipercaya, dan kepuasan pelayanan dalam mengembalikan fungsi organ reproduksi sediakala. Indentifikasi individu terhadap kelompok sosial yaitu adanya ketertarikan dan kebiasaan turun temurun memilih pengobatan dilakukan Odhe (hatra) dan "Bisa". Aspek budaya dari tradisi perawatan masa nifas yang harus dilakukan, yaitu pidaho wee musodo (mandi air panas), pirarai (panggang), kabongkoi (ikat pinggul/perut), dan meminum ramuan tradisional. Ditinjau dari aspek sosial masyarakat Buton Utara masih mempertahankan tradisi masa nifas sedangkan aspek budaya masyarakat masih berpegang teguh terhadap budaya yang telah diwariskan oleh nenek moyang secara turun temurun.
\end{abstract}

Kata kunci : Tradisi posoropu, masa nifas

\section{ABSTRACT}

The postpartum period is the period after the placenta is born and ends when the uterine devices return like pre-pregnancy conditions. Buton women make use of posoropu tradition as postpartum care that affects their health status. This study aims to explore the utilization of posoropu tradition during the postpartum period in Kulisusu District, Bonegunu District, \& North Kulisusu District in North Buton Regency. A qualitative study with Ethnographic approach, conducted with indepth interviews on 14 informants obtained with purposive sampling. rom the analysis of posoropu tradition during the postpartum period, consist of social aspect and cultural aspect. The social aspect of the female Buton has a self concept that the treatment performed by the Bisa (Shaman) cause a magical touch, trusted, \& service satisfaction in restoring the function of the reproductive organs in the past. Indentification of individuals to social groups that is the interest and habits of hereditary choose treatment done Odhe (hatra) and "Bisa". While the cultural aspects of postpartum care tradition that must be done, namely pidaho wee musodo (hot bath), pirarai (roasted), kabongkoi (belt/belly), and drinking traditional ingredients. Viewed from the social aspect of the people of North Buton still maintains the traditions of the puerperium while the cultural aspects of society still cling to the culture that has been inherited by ancestors from generation to generation. Keywords : Posoropu tradition, peurperium 


\section{PENDAHULUAN}

Indonesia terdiri dari ribuan pulau besar dan kecil yang dihuni ratusan suku bangsa dengan berbagai ragam budaya telah memberikan suatu kekhasan tersendiri. Perilaku masyarakat khususnya masyarakat tradisional tercermin dari perilaku mereka memanfaatkan kekayaan intelektual masyarakat lokal berupa pengetahuan tradisional mereka dengan keanekaragaman hayati dilingkungannya. ${ }^{1}$ Keragaman budaya adalah keniscayaan yang dimiliki bangsa indonesia. Di Indonesia keragaman budaya sesuatu yang tidak dapat pungkiri lagi keberadaanya. Dalam konteks pemahaman masyarakat majemuk, selain kebudayaan, masyarakat Indonesia juga terdiri dari berbagai adat dan kebudayaan daerah, bersifat kewilayahan yang merupakan pertemuan dari berbagai adat, kebudayaan kelompok suku bangsa yang ada di daerah tersebut. ${ }^{2}$

Berdasarkan hasil studi pendahuluan salah satu ragam budaya Indonesia terdapat di Sulawesi Tenggara Kabupaten Buton Utara. Setiap anak suku Buton mempunyai tradisi dalam perawatan masa nifas berupa mandi air panas (pibaho weemunsodo), ikat perut (kabongkoi), tanaman obat (ramuan obat), panggang (pirarai). Tradisi adalah segala sesuatu yang disalurkan atau diwariskan dari masa lalu ke masa kini atau sekarang. Dalam arti sempit adalah warisan-warisan sosial khusus yang memenuhi syarat saja yaitu yang tetap bertahan hidup dimasa kini, yang masih kuat ikatannya dengan kehidupan masa kini. Tradisi juga menjadi alasan dikalangan masyarakat hingga sekarang terkhusus pada perawatan ibu nifas. ${ }^{3}$ Fenomena tradisi perawatan masa nifas di belahan Asia, bahkan di beberapa tempat di Indonesia sendiri masih dilakukan, tetapi praktik posoropu diantara perempuan Buton belum pernah diungkap dan ditelisik lebih dalam, yang mana masih memiliki eksistensi dan diadopsi secara turun temurun dikalah ketatnya perkembangan teknologi kedokteran dimasa kini.

Dimensi budaya merupakan aspek penting dalam menentukan status kesehatan seseorang, masyarakat, dan bahkan suku bangsa. Segala unsur dalam masyarakat termasuk perilaku kesehatan dipe-ngaruhi oleh kebudayaan. ${ }^{4}$ Kegagalan intervensi masalah kesehatan antara lain karena tidak memahami sepenuhnya keberadaan manusia secara humanis, termasuk sisa budaya yang dianut. Berbagai upaya dilakukan, tetapi masalah belum dapat diselesaikan dengan optimal karena masih ada faktor budaya yang mempengaruhi kesehatan masyarakat yang belum disentuh. $^{5}$

Suatu penelitian kesehatan dalam perspektif kebudayaan, yaitu riset Etnografi kesehatan bertujuan menyikap kembali dan menggali nilai-nilai yang sudah bertimbun agar dapat diuji dan dimanfaatkan bagi peningkatan upaya pelayanan kesehatan dengan memperhatikan kearifan lokal. Informasi ini menjadi penting agar tidak menjadi "Tuna Budaya" kesehatan bangsa kita sendiri. Dengan mengetahui budaya setiap etnis diharapkan dapat membantu kelancaran dan keberlangsungan setiap program karena sentuhan budaya sebagai katalisator atau pelumas intervensi atau perubahan. ${ }^{6}$

Semakin disadari bahwa budaya tidak bisa diabaikan dalam mempengaruhi status kesehatan masyarakat. Oleh karena itu, riset tentang budaya kesehatan masyarakat dalam upaya peningkatan status kesehatan sangatlah penting untuk dilakukan. Konsekuensi logis harus disadari bahwa beranekaragaman budaya yang ada diwilayah Indonesia memerlukan pemahaman yang cermat untuk setiap daerah dengan etnis yang ada di wilayah tersebut. Pemahaman budaya secara spesifik, dengan menggali kearifan lokal akan dapat digunakan sebagai strategi upaya kesehatan dengan tepat secara lokal spesifik. ${ }^{7}$

Secara obyektif setiap kelompok masyarakat tertentu mempunyai persepsi kesehatan (konsep sehat sakit) yang berbeda. Hal ini sangat ditentukan oleh kebudayaan masyarakat yang bersangkutan. Setiap orang yang terganggu kesehatannya akan mencari jalan untuk menyembuhkan diri dari gangguan kesehatan atau penyakit yang dideritanya. Pencarian pengobatan dengan self treatment maupun upaya mencari tenaga kesehatan merupakan upaya manusia mengatasi permasalahannya. Budaya masyarakat yang menjadi ciri khas pola kehidupan, dan yang telah menjadi tradisi turun temurun, memiliki potensi yang besar untuk mempengaruhi kesehatan baik dari negatif maupun positif. Memahami status kesehatan masyarakat berdasarkan budaya merupakan salah satu upaya meningkatkan status kesehatan itu sendiri. ${ }^{8}$

Masalah kesehatan tidak terlepas dari faktor sosial budaya dan lingkungan di dalam masyarakat di mana mereka berada. Faktor-faktor kepercayaan dan pengetahuan budaya antara lain kepercayaan, pengetahuan, praktek atau perilaku mengenai berbagai pantangan, hubungan, sebab akibat antara perawatan masa nifas dan kondisi sehat sakit, kebiasaan dan pengetahuan tentang kesehatan, dapat membawa 
dampak positif maupun negatif terhadap kesehatan. ${ }^{9}$ Hal tersebut merupakan potensi dan kendala yang perlu digali, data dari Dinas Kesehatan Kabupaten Buton Utara jumlah ibu hamil 1.755 orang dengan Angka Kematian Ibu (AKI) 4 orang dengan penyebab kematian adalah pengetahuan ibu hamil yang kurang sehingga pada saat kehamilan dan masa persalinan hingga nifas telah terjadi pendarahan yang berakhir kematian. ${ }^{10}$ Sehingga penulis bermaksud untuk memaparkan pemanfaatan budaya posoropu dalam perawatan masa nifas oleh perempuan Buton Utara.

\section{BAHAN DAN METODE}

Jenis penelitian yang digunakan adalah jenis penelitian kualitatif dengan menggunakan rancangan Etnografi. Populasi dalam penelitian ini adalah seluruh masyarakat yang ada dalam lokasi penelitian yaitu wilayah Kecamatan Kulisusu, Kecamatan Bonegunu, dan Kecamatan Kulisusu Utara di Kabupaten Buton Utara dengan Informan penelitian sebanyak 14 orang partisipan yang didapatkan dengan purposive sampling. Partisipan merupakan masyarakat yang terlibat secara budaya dan pengaruh terhadap kesehatan baik dari segi tenaga kesehatan, tokoh-tokoh yang berpengaruh dan semua orang yang dapat memberikan informasi terkait dengan topik penelitian ini. Adapun teknik pengumpulan data dalam penelitian ini yaitu menggunakan triangulasi teknik dan sumber. Analisa data diperoleh dari hasil wawancara mendalam dilakukan secara manual sesuai dengan petunjuk pengolahan data kualitatif. Pengolahan data menuliskan hasil pengamatan, hasil wawancara kemudian diklasifikasikan, diinterprestasikan dan akhirnya disajikan dalam bentuk narasi.

\section{HASIL}

Dalam kebudayaan ada tata cara yang dilakukan oleh masyarakat di Kabupaten Buton Utara. Dalam proses terjadinya kehamilan pada saat laki-laki dan perempuan sudah resmi menikah maka dengan jalannya pernikahan tersebut maka kelak akan dikaruniai seorang anak. Perempuan hamil, setelah usia kandungan 7 (tujuh) bulan maka mereka melakukan upacara tujuh bulanan (Posipo). Pada hakekatnya tujuan dari upacara tersebut merupakan suatu doa atau amalan kepada yang maha kuasa semoga dalam proses kehamilan sam- pai melahirkan berjalan dengan mulus, yaituseorang ibu maupun bayinya selalu sehat dengan sajian beberapa jenis makanan tradisional. Selain itu, juga upacara tersebut dilakukan merupakan suatu syukuran bahwa mereka akan dikaruniai seorang anak. Setelah beberapa bulan kemudian terjadilah proses melahirkan. Selanjutnya etnis setempat melakoni tradisi Posoropu, yaitu tradisi perawatan masa nifas dilakukan setelah $\pm 2-3$ jam setelah melahirkan sampai masa nifas berakhir. Tradisi Posoropu dalam perawatan masa nifas diantaranya mandi air panas (pibaho weemusodo), sauna (pirarai), ikat perut (kabongkoi), dan minum ramuan. Tradisi ini dilakukan selama kurun waktu 40 hari dengengan di bantu bisa (dukun beranak).

Berdasarkan data dari hasil penelitian selama kurun waktu tujuh bulan didapatkan melalui wawancara, observasi dan pendokumentasian. Self concept masyarakat lokal Buton ditentukan oleh tingkat pengetahuan tentang masa nifas, serta keterbukaan terhadap orang lain saat merasakan kepuasan terhadap layanan dukun atau tenaga kesehatan yang diakses.

"Masa nifas merupakan keluarnya darah setelah melahirkan sampai berhenti"

(WR, 25 tahun)

Penuturan masa nifas oleh ibu WNA setalah kedua kalinya melahirkan, mengungkapkan pemahaman tentang masa nifas yang diukur dengan estetika postur tubuhnya yang kembali seperti semula.

"Sepengetahuan saya masa nifas dimulai dari setelah melahirkan sampai tubuh kembali sehat seperti sebelum hamil"

(WNA, 38 tahun).

Informan dengan usia 21 tahun menganggap masa nifas adalah masa menyakitkan karena selalu mengalami robekan disetiap kali melahirkan hingga anak ketiganya masih dialami hal serupa juga. Namun, memilih tetap hamil sampai mendapat anak lelaki dambaan keluarga mereka.

"Masa nifas ketika kita dalam keadaan merasa sakit dikarenakan robekan, proses melahirkan sampai sehat serta bisa berkebun lagi"

(WN, 21 tahun) 
Masa nifas dimulai dari setelah melahirkan sampai dengan berhentinya darah serta kondisi tubuh kembali keadaan seperti sebelum hamil. Setelah melahirkan \pm 2 sampai 3 jam keluarga mulai merundingkan tentang perawatan masa nifas yang akan diberikan oleh bisa (dukun). Jika sudah selesai berunding maka perawatan tersebut akan dilaksanakan sampai masa nifas berakhir. Hasil wawancara menunjukkan bahwa ibu merasa puas terhadap perawatan masa nifas yang diterima.

"Merasa sangat memuaskan dengan alasan karena setelah melakukan perawatan tersebut saya merasa nyaman"

(WNA, 38 tahun)

Hal serupa yang disampaikan oleh ibu WN, yang rajin melakukan kunjungan Posyandu, tetapi tetap memilih melahirkan dibantu oleh bisa.

"Puas dan senang. Alasannya karena dengan melakukan perawatan tersebut saya merasa sehat, cepat pulih dan cepat menyenangkan miaraha (suami) saya"

(WN, 21 tahun)

Sesuai dengan tingkat kepuasan yang dirasakan oleh ibu setelah melakukan perawatan masa nifas, dilihat dari segi kepuasan atas perawatan masa nifas yang diberikan oleh bisa (dukun) tentu ada rasa kepuasan tersendiri yang dirasakan oleh ibu tersebut karena perawatan yang dilakukan cukup baik serta saling mempercayai satu sama lain dalam menjalankan perawatan tersebut.

Identifikasi individu kepada kelompok sosial dikalangan perempuan Buton sangat penting untuk memberikan keamanan psikologis dan kepuasan dalam kehidupan mereka. Penjelasan terkait dengan penolong pada saat ibu atau bayi merasakan sakit.

"Saya langsung memanggil bidan, oleh karena bidan bertetangga rumah. $\mathrm{Na}-$ mun, yang paling utama saya panggil yaitu "odeh" karena dengan minum air yang ditiup (dibacakan doa-doa/mantra) saya merasa cepat sembuh dari sakit yang dialami. Begitu juga jika anak atau suami yang sakit"

(WP, 22 tahun)
Selain itu, senada dengan penuturan ibu WN yang selalu memanggil "Odeh" (Hatra) saat bayi atau dirinya mengalami kondisi sakit.

"Biasanya keluarga langsung panggil "odeh" untuk dibuatkan air herbal, serta dibacakan doa agar cepat sembuh dari rasa sakit yang dirasakan"

(WN, 21 tahun)

Pelayanan kesehatan bagi mereka memang sangat penting. Namun, kepercayaan terhadap pelayanan yang diberikan oleh odeh/hatra sangat berpengaruh terhadap kesembuhan. Oleh karena faktor tradisi atau kepercayaan yang dilakukan secara turun temurun oleh keluarga. Namun, istilah dari masyarakat berobat ke "Odeh", setelah itu ke puskesmas atau meminta tenaga kesehatan terdekat untuk melakukan pengobatan sesuai dengan keluhan yang dirasakan.

Tradisi dan nilai kebudayaan Buton Utara yang disalurkan atau diwariskan dari masa lalu ke masa kini masih berlaku di dalam masyarakat yang membentuk perilaku anak cucu mereka, seperti ibu-ibu yang menjalani tradisi masa nifas tetap dilakukan sesuai dengan yang diturunkan dari generasi ke generasi sekarang. Aspek budaya tradisi perawatan masa nifas yang harus dilakukan, yaitu pidaho wee musodo (mandi air panas), pirarai (panggang), kabongkoi (ikat pinggul/perut), dan meminum ramuan tradisional.

Kebersahajaan bisa yang lemah lembut dengan menuturkan proses mandi air panas (pibaho wee musodo) yang diberikan terhadap ibu nifas.

"Air yang dimasak dalam wajan berukuran 5 liter serta dicampurkan dengan daun pisang kering (mus acuminata balbisiana) dan tumbuhan katang-katang (ipomoea pescaprae) setelah mendidih air panas tersebut dimasukkan ke dalam baskom besar dan masak kembali air untuk mencegah air yang di dalam baskom tidak cukup untuk mandi, siapkan kain/baju serta air dingin secukupnya. Sebelum mandi air panas air dibacakan mantra atau doa-doa oleh Odhe agar mengurangi panasnya air dan juga pada saat mandi kulit tidak melepuh. Kemudian air tersebut dimandikan ke seluruh tubuh. Dan manfaat dari mandi air panas yaitu agar badan bersih, kuat, sehat, badan tidak 
sakit, keluar keringat dan darah kotor". (BM, 57 tahun)

Setelah proses mandi air panas dan pemijatan, dilanjutkan dengan menambahkan beban di atas perut ibu, yang diyakini dapat mengembalikan lingkar perut ibu sedia kala.

"Disamping dalam proses mandi air panas, ibu juga melakukan tindis perut dengan kelapa merah. Selain kelapa merah yang digunakan biasanya juga batu yang berukuran sedang alasannya agar perut mengecil atau kembali keadaan seperti sebelum hamil".

(BS, 46 tahun)

Masa nifas sangat erat kaitannya dengan hilangnya darah dari dalam tubuh seorang ibu, jadi saat proses tindis perut kelapa yang digunakan harus kelapa merah (Cocus Nucifera Ebunera) karena dipercaya memiliki khasiat dibandingkan jenis kelapa lainnya.

Selanjutnya hasil observasi peneliti terhadap bisa (dukun beranak). Dalam wawancara ini menjelaskan tentang langka-langkah perawatan oleh bisa terhadap ibu yang menjalani perawatan mandi air panas (pidaho wee mosodo). Sebelum ibu mandi air panas bagian seluruh tubuh, kecuali kepala, terlebih dahulu dibacakan doa atau mantra oleh bisa atau orang tua (ibu) agar tidak menyebabkan kulit melepuh dan dipercaya dapat mengurangi panasnya air. Tata cara yang dilakukan oleh bisa yaitu memandikan bagian seluruh badan dengan cara kain yang dicelupkan ke dalam baskom yang berisikan air panas seketika kain tersebut diletakkan pada bagian tubuh yang akan diinjak, ditekankan dan dipijat (diurut) yang dipercaya dapat mempercepat proses penyembuhan paska melahirkan.

Adapun tahapan proses pemijatan mandi herbal ini yakni ibu dalam posisi terlentang, cile (vagina) diinjak atau ditekan dengan satu kaki dan kedua tangan bisa berpegang pada paha ibu untuk mempercepat penyembuhan. Perut ditekan dan diurut (pijat) untuk mempercepat proses pengecilan. Kaki sampai paha ditekan dan diurut (dipijat) untuk melemaskan urat-urat (otot-otot) yang kaku (tegang). Selanjutnya ibu posisi menyamping kemudian bokong sampai cile (vagina) ditekan untuk mempercepat penyembuhan. Pinggul ditekan untuk melemaskan urat-urat (otot-otot) yang kaku (tegang). Lengan tangan, payudara sampai belakang badan dan ketiak ditekan dan diurut untuk melemaskan urat-urat (otot-otot) yang kaku (tegang) dan cici (payudara) untuk memperlancar ASI.

Langkah terakhir, ibu duduk kemudian bisa melakukan pemijatan pada bagian mata agar puanaka (darah putih) tidak naik ke kepala dan penglihatan terang. Pundak ditekan dan di urut (pijat) untuk melemaskan urat-urat (otot-otot) yang kaku (tegang). Jika seluruh badan (kiri dan kanan) telah diinjak, ditekan dan diurut (pijat) maka sisa air dalam baskom disiram ke seluruh badan.

Mengikat perut atau dikenal kabongkoi adalah hukumnya wajib bagi seorang ibu nifas perempuan Buton. Pengikatan ini bertujuan agar merasa kuat pada saat berdiri, berjalan dan kandungan tidak turun pada saat beraktivitas sebagaimana biasanya.

"Pengikatan ini tidak bisa dilepas selama
40 hari terkecuali pada saat mandi. Oleh
karena sebelum dilakukan pengikatan in-
dau (saya) membacakan doa pada pengikat
tersebut kemudian diikat dengan 2 lilitan
yaitu di atas pusat dan di bawah pusat. Ada-
pun bahan yang digunakan yaitu kain. De-
ngan ukuran panjang sesuai dengan kebu-
tuhan dan lebar $\pm 10 \mathrm{~cm}$, kemudian disemat-
kan jahe merah yang telah dimemarkan". (BS, 46 tahun)

Adapun langka-langkah kabongkoi oleh bisa adalah tali pengikat disisikan jahe yang berfungsi agar perut tetap hangat dan tali tersebut dibacakan doa/mantra kemudian dilakukan dengan mengikat perut bagian bawah (3 jari atas simpisis) dan perut bagian atas berfungsi untuk berjalan menjadi kuat dan menjaga kandungan tidak turun.

Setiap harinya seorang ibu nifas melakoni tradisi pirarai. Terlebih dahulu anggota keluarga menyalakan api ditungku yang sudah didesain di dalam kamar ibu. Tradisi ini dilakukan sampai masa nifas berakhir. Suhu atau panas tergantung dari keinginan atau kebutuhan dari informan itu sendiri yang diyakini bermanfaat bagi bayi yang dilahirkan memiliki fisik yang kuat, tidak masuk angin, dan tidak mudah terjangkit hepatitis. Bagi ibu, manfaat yang bisa dirasakan, yaitu mencegah 
darah putih naik ke kepala karena jika darah putih naik ke kepala maka dapat menyebabkan sakit kepala yang menetap, serta manfaat lainnya meredam hingga menghilangkan nyeri pada bagian pinggul.

"Pirarai (panggang) dilakukan dengan tujuan, yaitu agar cepat sehat, kuat, tidak masuk angin, tidak terkena penyakit kuningkuning, pinggul tidak sakit, mencegah darah putih naik ke kepala karena jika darah putih naik ke kepala maka dapat menyebabkan sakit kepala yang menetap. Adapun bahan dan alat yang digunakan yaitu tungku (tempat api) dan jenis kayu gamal."

(BM, 57 tahun)

Hasil observasi peneliti setiap paginya ibu nifas perempuan Buton secara konsistensi api dinyalakan dan ibu membelakangi api tersebut, sambil memangku bayinya yang rutin dilakukan setiap pagi dan sore hari. Paket perawatan posoropu yang tidak kalah penting adalah seorang ibu nifas diharuskan meminum ramuan karena obat dari Bidan tidak sepenuhnya dapat mempercepat proses penyembuhan.

"Indau (saya) percaya dengan mengonsumsi ramuan tersebut dapat menyehatkan tubuh, mengobati luka dalam dan mengeluarkan darah kotor".

(WNA, 38 tahun)

Meminum ramuan herbal yang diresepkan oleh bisa, pihak keluarga atau suami ibu nifas menghubungi odhe (hatra) sebagai peracik tanaman obat herbal, sesuai keluhan yang dirasakan ibu.

"Bahan yang digunakan untuk membuat ramuan tersebut yaitu kunyit, jahe dan gula merah. Kunyit dan jahe diparut kemudian dimasukkan ke dalam wajan berukuran kecil, ditambahkan air dan gula merah secukupnya lalu dimasak. Setelah mendidih air dari bahan tersebut dimasukkan ke dalam gelas (1/2 gelas) tunggu hingga hangat lalu diminum dua kali sehari."

(Od, 69 tahun)

Wawancara peneliti terhadap tenaga kese- hatan (bidan koordinator). Dalam wawancara ini menjelaskan tentang dampak positif dan negatif terhadap ibu yang menjalani tradisi perawatan masa nifas yaitu sebagai berikut:

"Secara keseluruhan tradisi yang dilakukan itu berdampak positif dan belum pernah kami dengar/lihat dampak negatifnya bagi masyarakat. Namun, bisa saja berdampak negatif contohnya jika pada saat proses persalinan terjadi robekan jalan lahir dan dilakukan penghektingan itu tidak boleh terkena air panas pada tempat hekting tersebut disebabkan benang jahitan akan meleleh atau putus, membelakangi api bisa saja berdampak negatif karena asap dari api tersebut dapat mengganggu sistem pernafasan pada bayi jika berada dalam satu ruangan atau didekat ibunya."

(Bikor, 32 tahun)

\section{PEMBAHASAN}

Budaya sangat berperan penting dalam kehidupan masyarakat lokal Buton Utara dalam menekuni perawatan masa nifas. Kearifan lokal budaya masih dipertahankan, mulai dari sistem perkawinan sampai memiliki keturunan, masih ter- bingkai rapi di dalam kehidupan mereka. Masa nifas diantara perempuan buton tidak berlalu begitu saja karena menurut mereka ini adalah masa yang sangat rentang dan menentukan urat nadi kehidupan seorang ibu, untuk kelak melahirkan generasi mereka selanjutnya. Adapun self concept dalam penelitian ini adalah tingkat pemahaman informan tentang kebiasaan masa nifas. Menurut Elisabeth, masa nifas adalah masa setelah plasenta lahir dan berakhir ketika alat-alat kandungan kembali seperti keadaan sebelum hamil. ${ }^{11}$ Masa nifas berlangsung $\pm 6-8$ minggu (42 hari). Penelitian ini dilakukan di Kecamatan Kulisusu dengan jumlah informan sebanyak 6 orang termasuk kategori ibu yang menjalani proses tradisi masa nifas dengan usia yang berbeda-beda. Dari 6 orang informan mereka mengetahui semua pengertian masa nifas akan tetapi penjelasan yang diutarakan tentang masa nifas tersebut berbeda-beda hal ini dibuktikan dengan hasil wawancara.

Dari perbedaan ini peneliti menarik kesimpulan bahwa perbedaan pengertian masa nifas dipengaruhi oleh tingkat pengetahuan yang 
dimilikinya. Menurut Notoatmojo, pengetahuan adalah hasil "tahu", dan ini terjadi setelah orang melakukan pengindraan terhadap suatu objek tertentu. Pengetahuan atau kognitif merupakan domain yang sangat penting untuk terbentuknya tindakan seseorang (overt behavior). ${ }^{12}$ Adapun tingkat kebiasaan masyarakat hal ini dibuktikan dengan masyarakat masih menggunakan dukun dikalangan Suku Buton. Dari semua tradisi masa nifas yang dijalani, semua informan mengatakan puas terhadap proses perawatan masa nifas yang dilakukan.

Tradisi adalah segala sesuatu yang disalurkan atau diwariskan dari masa lalu ke masa kini atau sekarang. ${ }^{13}$ Tradisi juga menjadi alasan di kalangan masyarakat hingga sekarang. Dari uraian teori tersebut bisa disimpulkan tradisi yang mereka pegang atau anut masih kuat dan tidak bisa diubah ataupun dihilangkan. ${ }^{14}$ Sehingga perempuan di Buton percaya bahwa ketika tidak melakukan tradisi perawatan masa nifas mereka akan cepat kelelahan pada saat beraktivitas, proses penyembuhan akan berlangsung lama, bahkan ibu berpotensi mengalami komplikasi yang memperberat status kesehatannya.

Identifikasi individu kepada kelompok sosial yang dimaksud dalam penelitian ini adalah ketertarikan informan terhadap kebiasaan masyarakat Buton Utara khususnya pada perawatan masa nifas dan kondisi lainnya. Ketertarikan dan kebiasaan informan dalam memilih pengobatan yang dilakukan jika bayi dan ibu merasa sakit. Dari beberapa informan berbeda-beda dalam memilih pertolongan pertama. Terdapat informan melakukan pertolongan pertama langsung ke bidan terdekat atau membeli obat ke apotik berdasarkan pengalaman yang dimiliki, informan lainnya masih melakukan pertolongan pertama dengan memanggil Hatra (Odeh). Jika tidak kunjung sembuh atau penyakit tersebut belum juga sembuh maka ibu atau bayi tersebut akan membawanya ke puskesmas atau meminta pertolongan ke bidan oleh keluarganya. Manusia adalah makhluk pembuat keputusan (decision-making man), pengambil keputusan, penentu atas sebuah pilihan dari sejumlah pilihan.

Tradisi yang dimaksud dalam penelitian ini adalah kondisi masyarakat telah mempercayai tradisi masa nifas dan nilai kebudayaan yang dimaksud dalam penelitian ini adalah suatu kebiasaan dan kepercayaan tentang tradisi dalam kehidupan sehari-hari. Faktor budaya Buton Utara terkadang membatasi perempuan untuk mengambil keputusan bagi kesehatannya, dari hasil penelitian menunjukkan bahwa informan memiliki pendapat yang berbeda-beda. Dari perbedaan tersebut, pendapat yang paling dominan dalam pengambilan keputusan adalah kepala keluarga atau suami dari ibu yang sedang menjalani proses perawatan masa nifas. Beberapa informan menjawab yang mengambil keputusan adalah orang tua dari ibu sedangkan suami, dan orang tua dari suami hanya pendukung pengambilan keputusan. Adapun tiap harinya suami memenuhi perlengkapan ritual tradisi masa posoropu yang harus dipenuhi atas saran Hatra dan Bisa.

Hal ini sesuai dengan hasil penelitian Bray JH dan Stanton M, yaitu kelompok individu memiliki keterkaitan satu sama lain. Keluarga merupakan unit yang tumbuh dan berkembang dan dipengaruhi oleh lingkungan sosial. ${ }^{15}$

Berdasarkan hasil wawancara dari informan tentang tradisi perawatan yang dijalani dalam proses masa nifas semua mengatakan melakukan tradisi masa nifas yang sama yaitu mandi air panas (pibaho wee musodo), panggang (pirarai), ikat pinggul/perut (kabongkoi), dan minum ramuan tradiosional. Walaupun jawaban dari masingmasing informan sama, tetapi masing-masing desa memiliki penciri waktu pemanfaatan posoro$p u$ yang menjadi pembeda tergantung dari pakem yang diayakini.

Menurut teori Taylor, seorang ahli antropologi yang merumuskan definisi tentang kebudayaan secara sistematis dan ilmiah, yang menyatakan bahwa kebudayaan adalah keseluruhan yang kompleks yang di dalamnya terkandung ilmu pengetahuan, kepercayaan, kesenian, moral, hukum, adat istiadat dan kemampuan lain serta kebiasaan yang didapat oleh manusia sebagai anggota masyarakat $^{5}$

Berdasarkan wawancara peneliti terhadap Bisa tentang tahap pelayanan tradisi posoropu terhadap informan yang menjalani perawatan masa nifas telah terungkap. Ibu menjalani pidaho wee musodo diguyuri dengan air panas dengan balutan kain yang ditambahkan tanaman obat, kemudian ibu mengambil posisi telentang lalu Bisa melakukan pemijatan dengan menggunakan telapak kaki 
di area vagina dengan menggunakan satu kaki bagian kanan dan kedua tangan Bisa bertumpuh pada lutut ibu, proses pemijatan ini diayakini mempercepat penyembuhan robekan pada vagina dan bagian dalam genetalia lainnya, sehingga organ vital ibu dapat kembali ke keadaan semula atau lebih rapat lagi.

Proses pemijatan pada bagian perut ditekan dan dipijat untuk mempercepat proses involusi uterus kembali normal. Kaki sampai paha ditekan dan dipijat untuk melemaskan otot-otot yang kaku (tegang). Posisi ibu menyamping, bokong sampai vagina ditekan untuk mempercepat penyembuhan. Pinggul ditekan untuk melemaskan otot-otot yang kaku (tegang). Lengan tangan, payudara sampai belakang badan serta ketiak ditekan dan diurut menggunakan tangan untuk melemaskan otot-otot yang kaku (tegang) dan payudara untuk memperlancar sikulasi aliran darah sehingga tidak terjadi bendungan ASI.

Berikutnya posisi duduk dan dilanjutkan pemijatan dengan tangan seputar area mata agar darah putih tidak naik ke kepala dan penglihatan terang. Pundak ditekan dan di urut untuk melemaskan otot-otot yang kaku (tegang). Setelah seluruh badan (kiri dan kanan) telah diinjak, ditekan dan diurut (pijat) maka sisa air dalam baskom disiram keseluruh badan, dengan harapan semua hal buruk ikut mengalir.

Pada praktik ini peneliti menyaksikan air yang dimasak dengan berbagai bahan tanaman obat dimasak menggunakan wajan yang sampai mendidih kemudian diangkat dari tungku, tanpa menunggu sampai hangat atau ditambahkan air dingin, dengan secarik kain yang digenggam oleh Bisa langsung dicelup ke wajan dan dibalutkan kebagian tubuh ibu, termasuk organ vital ibu sebelum dipijat. Namun, peneliti tidak menemukan terjadinya pelepuhan, tetapi jahitan di area vagina ibu terlepas, khususnya yang melahirkan menggunakan jasa tenaga kesehatan sangat rentang akan terjadinya pendarahan maka akan dirujuk jika dirasa perlu oleh keluarga atas persetujuan Bisa.

Alasan menggunakan air tanaman obat yang masih panas para Bisa menganalogikan vagina seorang ibu seperti ikan yang telah dibersihkan dan diiris, saat setelah dimasak bagian ikan tersebut seakan menyatuh kembali, meski masih menyisahkan tanda, tetapi bekas irisan tersebut menyatukan daging yang terpisah. Selain itu, air herbal yang panas mampu menghilangkan selulit dan stretch mark yang terjadi saat hamil sebelumnya.

Namun, praktik ini tidak hanya dilakoni anak perempuan Buton, demikian hal-nya sebagian orang Cina, India, \& Malaysia selama mandi herbal, suhu air harus hangat sampai panas (sebaiknya panas) dan dengan berbagai jenis herbal seperti Desmodium gangeticum (daun Meringan) ditambahkan. Pada saat yang sama, pijat sederhana di air dilakukan pada tubuh wanita sehingga melunakkan semua otot yang kencang dan tegang selama proses melahirkan. ${ }^{16}$

Sebelum dukun melakukan pengikatan, tali pengikat dari kain disisikan jahe yang telah dimemarkan, yang dipercaya dapat menghangatkan perut dan tali pengikat tersebut dibacakan mantra agar dapat mempercepat penyembuhan. Kemudian, dilakukan dengan mengikat perut bagian bawah (antara simpisis dan pusat) dan perut bagian atas (prosesus xifoideus) dipercaya ibu dapat melakukan mobilitas lebih cepat, kuat dan menjaga kandungan tidak turun (prolaps uteri).

Ritual selanjutnya yaitu ibu nifas melakoni tradisi pirarai (panggang) yang dijaga perapiannya agar ibu dan bayi tetap dalam kondisi keseimbangan antara panas/dingin, oleh suami sampai masa nifas ibu berakhir. Ibu membelakangi perapian tersebut dengan posisi duduk atau berbaring. Sementara di bagian dinding yang berlawanan posisi ibu tepatnya disamping perapian telah digantung kakak (plasenta) yang dibungkus dengan sabuk kelapa dengan takhayul pelasenta tersebut kering sebelum ditanam, sehingga tidak dimakan suanggi (hantu) karena diyakini plasenta yang masih berbau darah sangat rentang mengundang suanggi untuk mencelakai ibu dan bayi. Manfaat tradisi pirarai bagi bayi yang dilahirkan tidak mudah masuk angin, dan tehindar dari penyakit kuning (hepatitis), sedangkan bagi ibu manfaat yang bisa dirasakan, yaitu mencegah darah putih naik ke kepala, serta meredam hingga menghilangkan nyeri pada bagian pinggul, sehingga jika masa nifas ibu selesai sudah dapat melayani suaminya sedia kala.

Ulasan systematic review dari Withers $\mathrm{M}$, et al., di belahan Asia menunjukkan bahwa kepercayaan tradisional dan praktik masih memegang 
makna dan signifikansi berbagai budaya di Asia. Selain itu, sebagian besar kepercayaan tradisional dan praktik tidak berbahaya bagi wanita atau bayi mereka. Faktanya, memiliki banyak manfaat psikologis dan fisik bagi wanita. ${ }^{17}$ Bahkan Parsons $\mathrm{T}$, et al., menuturkan sepanjang tindakan dari individu yang dilakukan mempunyai makna atau arti subjektif bagi dirinya dan diarahkan kepada tindakan orang lain, sebagai prasyarat pilihan, dan lingkungan sekitar merasakan manfaatnya secara logis dan konsisten. ${ }^{18}$ Sehingga pirarai sebagai bagian dari praktik posoropu diantara perempuan Buton dizaman modern ini, masih memiliki eksistensi dan diadopsi secara turun temurun.

Hasil wawancara peneliti terhadap tenaga kesehatan (bidan koordinator), menjelaskan tentang dampak positif dan negatif terhadap ibu yang menjalani tradisi perawatan masa nifas. Dari tanggapan tenaga kesehatan (bidan koordinator) menyatakan bahwa secara keseluruhan tradisi yang dilakukan oleh masyarakat setempat berdampak positif disebabkan belum ada fakta atau isu-isu dalam melakukan tradisi masa nifas tersebut berdampak negatif bagi masyarakat. Berbicara berdampak negatif bisa terjadi, jika pada saat proses persalinan terjadi robekan jalan lahir dan dilakukan penghektingan itu tidak boleh terkena air panas pada tempat hekting tersebut benang jahitan akan meleleh/putus, membelakangi api bisa saja berdampak negatif karena asap dari api tersebut dapat menganggu sistem pernafasan pada bayi jika berada dalam satu ruangan atau di dekat ibu.

Kepercayaan tradisional dalam praktek selama kehamilan, persalinan, dan periode postpartum dikalangan perempuan Buton Utara. Perlu intervensi khusus oleh provider setempat untuk meemaksimalkan layanan kesehatan ibu. Program pendidikan tidak hanya ditujukan untuk perempuan, tetapi juga suami, orang tua, dan mertua. Dengan mengenali dan menghargai kepercayaan lokal setempat, provider bisa memanfaatkan dan atau memodifikasi posoropu untuk memberikan perawatan yang kompeten secara budaya. Alihalih mengurangi pilihan yang tersedia untuk perempuan Buton, penyedia layanan kesehatan harus memahami, menghormati, dan mengintegrasikan interpretasi budaya persalinan dan kebutuhan perempuan Buton dan keluarga mereka.

\section{KESIMPULAN DAN SARAN}

Dari penelitian ini dapat disimpulkan bahwa masyarakat Buton Utara masih mengunakan jasa dukun beranak dan hatra, jika dibandingan dengan jasa kesehatan, seperti bidan desa ataupun tenaga kesehatan lainnya. Hal ini disebabkan oleh tradisi kepercayaan yang dianut masyarakat setempat masih kental, di lain sisi masyarakat setempat masih kurang adanya pengetahuan tentang pentingnya bidan desa atau tenaga kesehatan lainnya. Selanjutnya saran bagi masyarakat hendaknya untuk berhati-hati dalam menjalani tradisi masa nifas dan bagi petugas kesehatan disarankan hendaknya memahami, menghormati, dan mengintegrasikan interpretasi budaya persalinan dan kebutuhan perempuan buton dan keluarga dalam melakukan intervensi kesehatan.

\section{DAFTAR PUSTAKA}

1. Robinson D. 3 Traditional Knowledge and Biocultural Diversity. Biodiversity Conservation in Southeast Asia: Challenges in a Changing Environment. 2017.

2. Dwiningsih S, Sri Mulyani, Semi Kawarakonda, Betty Roosihermiatie. Belenggu Apung Etnik Sumba Kabupaten Sumba Timur. Roosihermiatie B, editor. Jakarta: Lembaga Penerbitan Balitbangkes; 2014.

3. Wawan A, Dewi M. Teori dan Pengukuran Pengetahuan, Sikap dan Perilaku Manusia. Yogyakarta: Nuha Medika. 2010:15-20.

4. Manners RA. Professional Dominance: The social Structure of Medical Care: Routledge; 2017.

5. Ratna NK. Metodologi Penelitian Kajian Budaya dan Ilmu Sosial Humaniora pada Umumnya: Pustaka Pelajar; 2010.

6. Yunita Fitrianti., Fahmi Ichwansyah., Ari Wahyudi., Saifullah., Pratiwi NL. Etnik Gayo Desa Tetingi, Kecamatan Blang Pegayon Kabupaten Gayo Lues, Provinsi Nanggroe Aceh Darussalam. Jakarta: Percetakan Kanisius; 2012.

7. Angkasawati TJ. Studi Kasus Kesehatan Maternal Suku Muyu di Distrik Mindiptana, Kabupaten Boven Digoel. Jurnal Kesehatan Reproduksi. 2017;7(3):145-55.

8. Ahimsa-Putra HS. Kesehatan dalam Perspektif llmu Sosial Budaya. dalam Masalah Kesehatan dalam Kajian Ilmu Sosial-Budaya, Heddy Shri AP (ed) Yogyakarta: Kepel Press; 2005:13-38.

9. Rahayu IS, Mudatsir M, Hasballah K. Faktor 
Budaya Dalam Perawatan Ibu Nifas. Jurnal Ilmu Keperawatan. 2017;5(1):38-51.

10. Dinkes Kab. Buton Utara. Profil Kesehatan Kabupaten Buton Utara Provinsi Sulawesi tenggara Tahun 2017. Ereke: Dinas Kesehatan Kabupaten Buton Utara Provinsi Sulawesi Tenggara; 2017.

11. Walyani ES, Purwoastuti E. Asuhan kebidanan masa nifas dan menyusui. Yogyakarta : PT Pustaka Baru; 2015.

12. Notoatmodjo S. Ilmu Perilaku Kesehatan. Revisi ed. Jakarta: Rineka Cipta; 2014.

13. Turner SP. The Social Theory of Practices: Tradition, Tacit Knowledge and Prepositions: John Wiley \& Sons; 2018.

14. Heinz CB, Murray JA. Asian cultural traditions: Waveland Press; 2018.
15. Bray JH, Stanton M. The Wiley-Blackwell HandBook of Family Psychology: John Wiley \& Sons; 2012.

16. Yusoff ZM, Amat A, Naim D, Othman S, editors. Postnatal Care Practices among the Malays, Chinese and Indians: A Comparison. SHS Web of Conferences : EDP Sciences; 2018.

17. Withers M, Kharazmi N, Lim E. Traditional Beliefs and Practices in Pregnancy, Childbirth and Postpartum: A Review of the Evidence from Asian Countries. Midwifery. 2018;56:158-70.

18. Parsons T, Staubmann H, Lidz V. An Approach to the Analysis of the Role of Rationality in Social Action. Rationality in the Social Sciences: Springer; 2018:53-7. 